\title{
Činnost $v$ tanečních souborech a její vliv na formování osobnosti jedince
}

\author{
Activity in dance ensembles, and its influence on the formation of individual personality \\ Helena Pilušová
}

\begin{abstract}
Abstrakt: Př́spěvek představuje zamýšlené propojení kvalitativní a kvantitativní metody sběru dat, které je zacíleno na činnost ve folklorních tanečních souborech a jeho vlivu na formování tanečníkovy osobnosti. Cíle je zjistit, zda aspekty podporující motivaci k výkonu ve volnočasové sociální skupině mohou ovlivňovat i motivaci k výkonu ve škole a celkové životní nastavení jednotlivce.
\end{abstract}

Klíčová slova: taneční soubory, volný čas, výkonová motivace, osobnost

\begin{abstract}
Post will present the proposed linking qualitative and quantitative methods of data collection, which is targeted to work in folk dance ensembles and its influece on the formation of dancers personality. The investigation is focused on determining whether aspects of supporting the motivation to exercise in lesure social group can influece the motivation to perform in the school setting and overall life of the individual.
\end{abstract}

Keywords: dance groups, leisure, power motivation, personality

\section{1 Úvod}

Volný čas a jeho smysluplné trávení má své nezastupitelné místo v životě každého z nás. Zvláště nazíráme-li na tento fenomén optikou dnešního uspěchaného a prací zahlceného člověka. Často konstatujeme, že volného času máme málo a proto si aktivity, kterým se mimo rámec svých pracovních povinností chceme věnovat, pečlivě vybíráme. Nejinak je tomu u členů tanečních souborů, na které je zaměřeno naše výzkumné šetření. Ti do svých souborů docházejí často od dětství až do dospělosti, nacházejí zde přátele, vnímají tuto činnost jako možnou formu fyzické aktivity, tak i jako způsob formování sebe sama a nalézání cesty k sobě samému. Být členem skupiny je zavazující, zvláště pak skupiny, jejímž cílem je prezentace daného typu aktivity formou veřejných vystoupení před publikem, jak je tomu právě v př́ípadě tanečních souborů. Tato činnost tedy vyžaduje zapojení a nasazení celého člověka.

\section{Taneční soubor}

Taneční folklorní soubor, stejně jako jiné formy organizovaného trávení volného času, lze vnímat jako sociální skupinu, jejíž počet většinou nepřesáhne 35 osob, její členové se vzájemně znají, vstupují do vzájemných interakcí. Díky tanečnímu souboru rovněž dochází k oboustrannému procesu formování - skupiny i jednotlivce. (srov. Králová \& Čech, 2007, in Čech, s. 86). Tato skupina poskytuje svým členům prostor pro naplňování osobních potřeb, seberealizaci, vnímání sebe sama v rámci vnitřních skupinových vztahů. Tanečník ve skupině dozrává, hledá v ní své místo. V životě tanečníků představuje činnost v souboru nenahraditelnou hodnotu, která mnohé ovlivňuje i v běžném životě, životním stylu. „Tanec je 
jednou z nejstarších forem umění. Je souborem komunikačních symbolì, odráži a uspořádává zkušenosti, reprezentuje prožitky ze života člověka, má intencionální charakter. (Králová \& Čech, 2007, in Čech, s. 85). Činnost v tanečním souboru naplňuje hned několik východisek podílejících se na formování jedincovy osobnosti. Jedním z nich je hledisko pedagogické. Obdobně jako ve školní edukační realitě, dochází i zde, v rámci volnočasových aktivit, $\mathrm{k}$ významnému vzájemnému působení a ovlivňování. Za jednu $\mathrm{z}$ velmi důležitých pedagogických konsekvencí této činnosti lze považovat i prevenci sociálně patologických jevů. Z psychologického hlediska je nutno zmínit vnímání sociální dynamiky, proces proměny sociálních rolí v rámci skupiny, vývoj vzájemných vztahů, ovlivňování a utváření životního stylu. Tato fakta hrají důležitou roli pro předávání a získávání životních zkušeností. Taneční soubory také dobře slouží jako socializační prvek a poskytují svým členům rovněž dostatečný prostor pro začlenění do sociálních struktur. Jedná se o procesy a děje, které se odehrávají v nitru jedince, probíhající celoživotně a formulující sociální a kulturní osobnost. (srov. Reichel, 2008, s. 158-159). Nezanedbatelné není ani hledisko fyzické aktivity. Z hlediska fyzického vyžití lze činnost $\mathrm{v}$ tanečních souborech přirovnat $\mathrm{k}$ jakékoli jiné sportovní aktivitě. Většina členů vnímá tuto činnost i jako možnost zlepšení či udržení dobré fyzické kondice, proto můžeme na tuto aktivitu nazírat jako na takovou, která „nabízi pozitivní impulzy aktivního prístupu ke zdraví a fyzické kondici“" (Krawczyk, 2008, in Sekot, s. 30).

\section{Motivace}

Docházení do tanečního souboru a vykonávání této činnosti je založeno na působení vnitřních pohnutek či vnějších podnětů. Pro mnohé tanečníky je motivací už jen samotná možnost být členem některého ze souborů. Většina z nich zde nachází príležitost pro sebeuplatnění realizované prostřednictvím vykonávané činnosti. Mnohdy právě při této činnosti se rozkrývají charakterové vlastnosti jednotlivců, tady právě dochází k nejsilnějšímu působení na mladé členy, kteří pod vlivem emočních prožitků, pocitů, vzniklých vazeb či zázemí, ve kterém se cítí př́ijemně, posuzují své další působení v souboru, které častokrát ovlivní i celkové názorové směřování v životě.

\subsection{Motivace $k$ činnosti}

Pro tuto činnost je nezbytné také osobní nasazení, vnitřní přesvědčení, zápal a neutuchající nadšení. Bez těchto silných motivačních faktorů by ani pohybová ani sociální složka nedošly naplnění. Proto je neodmyslitelně důležitá i motivace. Jsou-li vnitřní nastavení člena a vykonávaná činnosti v souladu, síla motivace se znásobuje a může být nakonec tak silná, že je jedinec schopen věnovat činnosti maximum času, úsilí, nasazení, představuje pro něj něco, kvůli čemu je schopen projit ohněm. (srov. Kern et al., 1999, s. 53)

\subsection{Motivace $k$ výkonu}

V rámci taneční prezentace na jevišti, což je možno považovat za jeden z hlavních cílů těchto skupin, hraje velkou roli rovněž motivace $\mathrm{k}$ dobrému výkonu. Ta je v literatuře popsána ze dvou základních hledisek a to motivace k výkonu a motivace vyhnutí se neúspěchu. Princip tanečního souboru, jehož hnací silou je mimo jiné i podávání co nejlepšího výkonu v tanci při vystoupeních na veřejnosti, může podněcovat stejně tak i podávání stejně dobrého výkonu ve škole. Máli být tedy činnost efektivní, musí být v souladu s celkovou sebeakceptací (přijetí sebe sama). Lze tedy předpokládat, že osobní pojetí tohoto druhu volnočasové činnosti s sebou zároveň nese i totéž nastavení pro plnění dalších povinností a prímo ovlivňuje i celkový přístup k životu. 


\section{Cíle a záměr}

Při stanovení výzkumného cíle a záměru vycházíme právě z předpokladu, že každá volnočasová činnost by měla vykazovat alespoň základní prvky organizovanosti, smysluplnosti a systematičnosti. Aby činnost byla plynulá a nedocházelo k výkyvům v právě uvedených prvcích, hraje podstatnou roli motivace. Ohnisko našeho zájmu leží ve zjištění, zda může motivace $\mathrm{k}$ výkonu $\mathrm{v}$ tanci ovlivňovat i motivaci tanečníka $\mathrm{k}$ výkonu ve škole. Pomocí výzkumného šetření se pokusíme zjistit, zda činnost v tanečním souboru provázena všemi faktory včetně motivace k výkonu, může ovlivnit formování tanečníkovy osobnosti.

\section{Metody}

Pro výzkumnou část práce byla zvolena kombinace kvalitativního a kvantitativního způsobu šetření. Pro získání kvantitativních dat uvažujeme o on-line aplikaci Dotazníku motivace k výkonu- LMI autorů Schulera a Prochasky, českém překladu Hoskovcové. Tato data doplníme o fenomenologické zkoumání za účelem porozumění fenoménu tanečních souborů a jejich významu v životě daných účastníků výzkumného šetření.

\subsection{Oživená fotografie-fenomenologie}

Hlavním důvodem pro volbu metody oživené fotografie byla časová provázanost činnosti a její longitudinální charakter. "Cílem fenomenologického zkoumáni je popsat a analyzovat zkušenost se specifickým fenoménem, kterou má určitý jedinec nebo skupina jedincü“ (Hendl, 2008 , s. 126). K popsání zvoleného principu nás vedla zásadní otázka - co je za tím? K podpoře plánovaných rozhovorů zamýšlíme využít fotografií ze souborových kronik, které budou respondentům předkládány za účelem vybavení př́ihody, silných okamžiků, prožitků spojených s činností v souboru. Data budou získána na základě kvalitativních rozhovorů $\mathrm{s}$ účastníky.

\subsection{Dotaznikové šetření}

Dotazníkové šetření zvolenou metodou LMI bylo vybráno především z důvodu možnosti lokálního testování na počítači, vhodnosti pro zvolenou věkovou skupinu (členové souborů ve věku 15-18let) i délky samotného vyplnění dotazníku (30-40minut). Dotazník LMI poslouží jako podpůrná doplňková metoda pro hlubší porozumění osobnostně teoretickému pozadí, které tvoří chápání motivace k výkonu jako podíl osobnosti na vlastní výkonnosti.

\section{Závěr}

V době rychlých změn a vývoje je orientace v sobě samém, stanovení osobních cílů a vynaložení úsilí k jejich dosažení nezbytným prvkem pro začlenění do sociálních uskupení, pro vnímání sebeuplatnění. Nezastupitelnou roli zde hraje sounáležitost k sociální skupině, díky níž se jedinec stává součástí principů působících formulačním a určujícím způsobem na vlastní nastavení a motivaci kvýkonu a vnímání této osobní zkušenosti v kontextu celoživotního směřování. Taneční soubory poskytují svým členům možnost seberealizace, nabízejí podněty k získávání zkušeností a předkládají motivační principy pro nastavení $\mathrm{k}$ podávání výkonu $\mathrm{v}$ tanci. Naším záměrem je zjistit, jakou roli přisuzují jednotliví aktéři tomuto fenoménu a jak se zkušenost s motivací k výkonu odráží u zvolené cílové skupiny ve školním prostředí, potažmo v celkovém nastavení osobnosti. 


\section{Literatura}

Čech, T. (Ed.). (2007). Výchova a volný čas. Brno: MU.

Hendl, J. (2008). Kvalitativni výzkum. Praha: Portál.

Kern, H. et al. (1999). Přehled psychologie. Praha: Portál.

Reichel, J. (2008). Kapitoly systematické sociologie. Praha: Grada.

Sekot, A. (2008). Sociologické problémy sportu. Praha: Grada.

Schuler, H., \& Prochaska, M. (2011). Dotaznik motivace k výkonu. Praha: Testcentrum.

\section{Kontakt}

Mgr. Helena Pilušová

Masarykova univerzita

Pedagogická fakulta, Katedra sociální pedagogiky

Poříčí 31, 60300 Brno

e-mail: helena.pilusova@post.cz

\section{Bibliografické údaje}

Pilušová, H. (2011). Činnost v tanečních souborech a její vliv na formování osobnosti jedince. In T. Janík, P. Knecht, \& S. Šebestová (Eds.), Smišený design v pedagogickém výzkumu: Sborník přispěvki̊ z 19. výročni konference České asociace pedagogického výzkumu (s. 368-371). Brno: Masarykova univerzita.

Dostupné z: http://www.ped.muni.cz/capv2011/sbornikprispevku/pilusova.pdf doi: $10.5817 /$ PdF.P210-CAPV-2012-45 